NBER WORKING PAPER SERIES

\author{
MONETARY POLICY IN OPEN ECONOMIES \\ Richard Clarida \\ Working Paper 20545 \\ http://www.nber.org/papers/w20545
} PRACTICAL PERSPECTIVES FOR PRAGMATIC CENTRAL BANKERS

\author{
NATIONAL BUREAU OF ECONOMIC RESEARCH \\ 1050 Massachusetts Avenue \\ Cambridge, MA 02138 \\ October 2014
}

Paper prepared for the Hoover Institution Conference on Monetary Policy for the 21st Century. I would like to thank the conference organizers, participants, and especially my discussant Maurice Obstfeld as well as Ken Judd for insightful suggestions for future work. The views expressed herein are those of the author and do not necessarily reflect the views of the National Bureau of Economic Research.

The author has disclosed a financial relationship of potential relevance for this research. Further information is available online at http://www.nber.org/papers/w20545.ack

NBER working papers are circulated for discussion and comment purposes. They have not been peerreviewed or been subject to the review by the NBER Board of Directors that accompanies official NBER publications.

(C) 2014 by Richard Clarida. All rights reserved. Short sections of text, not to exceed two paragraphs, may be quoted without explicit permission provided that full credit, including $\odot$ notice, is given to the source. 
Monetary Policy in Open Economies: Practical Perspectives for Pragmatic Central Bankers

Richard Clarida

NBER Working Paper No. 20545

October 2014

JEL No. E52,E58,F3

\begin{abstract}
$\underline{\text { ABSTRACT }}$
This paper reviews and interprets some of the key policy implications that flow from a class of DSGE models for optimal monetary policy in the open economy. The framework suggests that good macroeconomic outcomes in open economies are possible by focusing inflation targeting that is implemented by a Taylor type rule, a rule that in equilibrium is reflected in the exchange rate as an asset price. Optimal monetary policy will not be able deliver a stationary ('stable') nominal exchange rate - let alone a fixed exchange rate or one that remains inside a target zone because, absent a commitment device, optimal monetary can't deliver a stationary domestic price level. Another feature in the data for inflation targeting countries that is consistent with monetary policy via Taylor type rule is that it will tend push the nominal exchange rate in the opposite direction from PPP in response to an 'inflation' shock the 'bad news god news' result of Clarida -Waldman (2008;2014). This is so even though in the long run of these models the nominal exchange rate must in expectation obey PPP.
\end{abstract}

\author{
Richard Clarida \\ Columbia University \\ 420 West 118th Street \\ Room 1111, IAB \\ New York, NY 10027 \\ and NBER \\ rhc2@columbia.edu
}




\title{
Monetary Policy in Open Economies: Practical Perspectives for Pragmatic Central Bankers
}

\author{
Richard H. Clarida* \\ C. Lowell Harriss Professor of Economics \\ Columbia University and NBER \\ rhc2@columbia.edu
}

May 19, 2014

\section{Introduction}

The theory and practice of conducting monetary policy in the global economy has evolved and, along many dimensions, converged over the past twenty years. In the fifteen years before the world financial crisis, this was evident in the widespread adoption of inflation targeting, flexible exchange rates, and of policy implementation well understood and evaluated within a Taylor Rule framework. Empirical research suggest that the apparent convergence to a Taylor Rule framework did in fact occur during this period (Clarida and Gertler (1996); Clarida, Gali, Gertler (1998;2000); Clarida (1999;2001;2009); Lubik and Schorfheide (2003); Engel and West (2006); Molodtsova and Papell (2009)). We believe this convergence was no coincidence. In fact, building on the research program introduced in Taylor (1982;1993) and advanced by Obstfeld and Rogoff (1996;2000) and Svensson (2000), a number of papers (Clarida, Gali, Gertler (2001;2002); Obstfeld (2002); Corsetti and Pesenti (2005); Gali Monacelli (2005)); Engel (2009); Woodford (2010); Devereux and Hnatkovska (2011)) among others show that, in dynamic stochastic general equilibrium models with nominal rigidities, flexible exchange rates and inflation targeting produce desirable macroeconomic outcomes in open economies. Indeed under certain conditions and in particular models, inflation targeting implemented by a Taylor rule in a regime of flexible exchange rates characterizes the optimal monetary policy for a central 
bank seeking to maximize a well specified social welfare function in an open economy This paper reviews several of the most relevant findings from this literature, findings that until now have been and likely will, in the future be, of practical interest to pragmatic central bankers conducting monetary policy in the global economy of the $21^{\text {st }}$ century. The focus will be on implications from this research that, in our opinion, are most likely in the decades ahead to be robust in practical, real-world application, not just in the particular theoretical models from which they were originally derived.

The plan of the paper is as follows. In Section II we review the set-up of the open economy DSGE model introduced in Clarida, Gali, Gertler (2001;2002), Gali Monacelli (2005)) and Gali (2008) and extended by, among others, Engel (2009)); Woodford (2010), and Devereux and Hnatkovska (2011). We provide intuition for the 'isomorphism result' tightly linking optimal monetary policy in open and closed economies that is a property of a class of models discussed in Clarida, Gali, Gertler $(2001 ; 2002)$. In Section III we solve for optimal monetary policy and highlight several key and we believe robust implications of the above cited DSGE literature for open economy monetary policy operating away from the zero lower bound. We are motivated by a belief that as the world's major central banks begin to normalize policy rates and escape (finally!) from the zero bound, the Taylor Rule framework will re-emerge as the preferred de facto if not de jure construct for conducting, evaluating, and ultimately for communicating monetary policy, with the crucial understanding that....

The neutral real interest rate, a key input to Taylor rule analysis, appears in practice to be time varying (Laubach and Williams (2001)), and this time variation is likely to be more important in the future than in the past for calibrating monetary policy. In particular, the neutral real interest rate in the open economy will in general be a function of global as well local factors such as the rate of potential growth.... 
- The exchange rate is an asset price will reflect expectations of the future time path of the policy rate as summarized by the policy rule and thus the expected future time path of inflation and output under the policy rule. One important empirical implication of monetary policy by Taylor rule in the open economy is that 'bad news about inflation can be good news for the nominal exchange rate' (Clarida and Waldman 2008); see also the discussion in Krugman, Obstfeld, Melitz (2011) even though with inflation targeting, bad news about inflation must in expectation be bad news for the long run level of the nominal exchange rate. Moreover, ......

- In the absence of a commitment device that binds central banker and their successors, optimal monetary policy in the open economy can at most achieve a stationary rate of inflation not a stationary price level. In other words, price level targeting is not in general time consistent in the class of DSGE models cited above, a direct consequence of Clarida, Gali, Gertler (1999); Woodford (2003); and the isomorphism result in Clarida, Gali, Gertler $(2001 ; 2002)$ and Gali- Monacelli (2005). As a result, even if the equilibrium terms of trade are stationary, the equilibrium nominal exchange rate under an optimal policy will resemble a random walk. Technically it will possess a unit root but in fact will be co integrated with the price level. In other words...

- A regime of fixed exchange rates is a 'mirage' (Obstfeld and Rogoff (1996)) in the sense that in these economies it is not time consistent in the presence of nominal rigidities for the policymaker who is maximizing household welfare to promise fix the exchange rate . Moreover, in general, while PPP may be expected to hold in the long run...... 
- The persistence of PPP deviations will in general depend directly on the policy rule in economies in which inflation 'inertia' is endogenous. Theoretically (Clarida Waldman $(2008 ; 2014)$, the greater is the relative weight the policy maker places on output stabilization relative to inflation stabilization, the greater will be the equilibrium half-life of PPP deviations. Clarida and Waldman (2008) report an empirical announcement effect study (Table 1) that documents the bad news good news correlation in high frequency data for G10 countries over the 2001-2005 period. Clarida - Waldman (2014) update the original announcement effect study to span 2001-2013 period and show (Table 2) that the 'bad news good news' effect remains a robust feature of the data on days when there are inflation announcements..

In Section IV we present an analysis based on Clarida and Waldman (2014) who use a small open economy version of the Gali - Monacelli (2005) model with a hybrid Phillips curve to generalize and extend the findings of Clarida - Waldman (2008) with regards to the 'bad news good news' result as well as the endogenous persistence of PPP deviations under optimal monetary policy. Section V concludes.

\section{A Model}

Clarida, Gali, Gertler (2001;2002) and Gali - Monacelli (2005) study a class of DSGE models with nominal rigidities that can be used to analyze optimal monetary policy in open economies and the role of the nominal exchange rate in the transmission mechanism. These models have been fruitfully extended in subsequent work by Engel (2009); Woodford (2010); and Devereux and Hnatkovska (2011) among others. Clarida, Gali, Gertler (2001) and GaliMonacelli (2005) are models of small open economies while Clarida, Gali, Gertler (2002) is a general equilibrium two country model. Focusing on the 'home' economy, the basic set up of these models is as follows. 
The home economy produces a tradable consumption good from a CES continuum of differentiated intermediate inputs, each of which is produced with a linear technology over a CES bundle of differentiated varieties of labor. The elasticity of substitution among intermediate inputs is $\xi>1$ and the elasticity of substitution among varieties of labor is $\eta_{t}>1$, with $\eta \mathrm{t}$ a stationary stochastic process. Nominal wages are flexible and each worker earns the same wage $\mathrm{W}(\mathrm{t})$, but the nominal price of each input can only be re set at random discrete intervals as in Calvo (1983). As in Woodford (2003), there will be a welfare cost to domestic inflation with this Calvo pricing assumption, because inflation will change the relative prices of inputs and thus cause final output to be inefficiently produced. This welfare cost will be decreasing in $\xi$.

Households have Cobb-Douglass preferences over a consumption index $C_{t}$ comprised of the home produced final good and a differentiated consumption good produced abroad. A key parameter is $\gamma$ which is the share of home spending on the foreign good. The larger is $\gamma$, the more open is the home economy. The law of one price holds and there is producer currency pricing. The relative price of the foreign produced consumption good in terms of the home produced consumption good, the terms of trade, is denoted by $S_{t}=E_{t}\left(P^{*}{ }_{t} / P_{t}\right)$ where $E_{t}$ is the nominal exchange rate and $\mathrm{P}_{t}$ and $\mathrm{P}_{\mathrm{t}}^{*}$ are producer currency prices of goods for export in home and foreign.

Utility takes the standard form

$$
U\left(C_{t}\right)-V\left(N_{t}\right)=\frac{C_{t}^{1-\sigma}}{1-\sigma}-\frac{N_{t}^{1+\phi}}{1+\phi}
$$

Where $1 / \sigma$ is the intertemporal elasticity of substitution of consumption, and $N_{t}$ is labor supply. We will focus on the benchmark case with $\sigma \geq 1$ but derive many of our results for the general $\sigma>$ 0 case as well. 
Households maximizes a discounted sum of expected utility with a discount rate $\beta$ subject to a sequence of budget constraints

$$
P_{t}^{c p i} C_{t}+E_{t}\left\{M_{t, t+1} D_{t+1}\right\}=W_{t} N_{t}+D_{t}-T_{t}+\Gamma_{t}
$$

where $M_{t, t+1}$ is a nominal stochastic discount factor, $\mathrm{D} t$ is the distribution paid on securities brought into date $t, T_{t}$ is lump sum tax collection, and $\Gamma_{t}$ is the distribution of profits earned by producers of intermediate inputs.

Firms will set prices as a mark up over marginal cost. Given the linear technology, real marginal cost is just the real product wage scaled by productivity $M C_{t}=(1-\tau)\left\{W_{t} / P_{t}\right\} A_{t^{-1}} \quad$ In our open economy this can be written as $M C_{t}=(1-\tau) k^{-1}\left\{W_{t} / P^{c p i}{ }_{t}\right\} S_{t} A_{t} t^{-1}$ where $P_{t}^{c p i}=k^{-1} P_{t} S_{t}^{\gamma}$ is the CPI, $\mathrm{P}_{\mathrm{t}}$ is the price of the consumption good produced at home, $\tau$ is a wage tax or subsidy, and $k=(1-\gamma)^{(1-\gamma)} \gamma^{\gamma}$. The first order condition for labor supply implies $W_{t} / P^{c p i}=\left(1+\mu_{t}^{w}\right) N_{t}^{\phi} C_{t}^{\sigma}$ where $1+\mu_{t} w=\eta_{t} /\left\{\eta_{t}-1\right\}$ is a wage mark up. They key thing to note is the distinction between the real product wage $W_{t} / P_{t}$ that is relevant for the labor demand and the real CPI wage that is relevant for labor supply. Unlike in the closed economy, these differ in the open economy because of the terms of trade. This is crucial for understanding the open economy Phillips curve to be derived below. Substituting for the real CPI wage we obtain a structural equation for real marginal cost in the open economy $M C_{t}=(1-\tau)\left(1+\mu^{w}{ }_{t}\right) N^{\phi}{ }_{t} C_{t}^{\sigma} S_{t}^{\gamma} k^{-1} A^{-1} t$.

Price setting by intermediate goods producers is staggered as in Calvo (1983), resulting in an open economy Phillips curve for domestic inflation as a function of the deviation of log real marginal cost from its steady state level of $\log (\xi /(\xi-1))$ with $1+\mu^{\mathrm{p}}=\xi /(\xi-1)$ the desired markup over nominal marginal cost by intermediate goods producers. We have 
$\pi_{t}=\beta E_{t} \pi_{t+1}+\delta m c_{t}$ where lower case letters denote log deviations from the non-stochastic steady state and $\delta=(1-F)(1-\beta F) / F$ with $(1-F)$ the fraction of firms that reset prices each period. It is useful to write out the open economy Phillips curve explicitly in terms of endogenous variables and the productivity and cost push realizations

1)

$$
\pi_{t}=\beta E_{t} \pi_{t+1}+\delta\left(\phi y_{t}+\sigma c_{t}+\gamma s_{t}-(1+\varphi) a_{t}\right)+\delta \mu_{t}^{w}
$$

where we have used the fact that $n_{t} \approx y_{t}-a_{t}$, with the approximation due to the omission of a second order term that captures the inefficient demand for labor resulting from the dispersion of domestic relative prices in an economy staggered pricing and non-zero inflation.

For households, an Euler equation will characterize the equilibrium relationship between the log consumption index, CPI inflation, and the one period nominal interest rate $R_{t}$

$$
c_{t}=E_{t}\left\{C_{t+1}\right\}-\frac{1}{\sigma}\left(R_{t}-E_{t} \pi_{t+1}-\gamma E_{t} \Delta s_{t}+1\right)
$$

where $\pi_{\mathrm{t}+1}$ is the rate of inflation in domestic goods prices. Again, recall that in the open economy CPI inflation is a function of the change in the equilibrium terms of trade as well as inflation in the price of domestically produced goods. 


\section{An Isomorphism Result}

Inspection of equations 1) and 2) reveals that in the special case with $\gamma=0$ the system reduces to the standard closed economy DSGE model (Clarida, Gali, Gertler (1999);Woodford (2003)). That model is closed with a goods market equilibrium condition $c_{t}=y_{t}$ and specification of a policy rule for $R_{t}$ as a function of $\pi_{t}$ and $y_{t}$ (and perhaps other, exogenous variables such as productivity growth or government spending). Moreover, an optimal policy rule can be derived for the $\gamma=0$ version of the model for a loss function that is quadratic in inflation and the gap between $y_{t}$ and its level $\bar{y}_{t}$ under flexible prices. And indeed, Clarida, Gali, Gertler (1999) show that the optimal monetary policy in the closed economy can be written as a version of a Taylor rule.

But how does one close the open economy model sketched out above? Although there are number of ways to do this (see Obstfeld (2002); Corsetti and Pesenti (2005) and Engel (2009) for alternatives), there are two known cases consistent with global general equilibrium that will result in a set of equilibrium conditions exactly isomorphic to the closed economy analysis in Clarida, Gali, Gertler (1999). These results are derived in Clarida, Gali, Gertler (2002) and Gali Monacelli (2005). Both cases require that preferences be Cobb-Douglas, and each case is a direct implication of the insightful analysis of Cole and Obstfeld (1991). The isomorphism result will obtain for any $\sigma>0$ if home and foreign Cobb-Douglas utility functions are identical (Clarida, gali, Gertler (2002)). The isomorphism result will also obtain with differing home and foreign Cobb-Douglas utility functions - say featuring a bias for domestically produced goods - if $\sigma$ is identically equal to 1 across countries (Gali and Monacelli (2005)). As shown by Cole Obstfeld (1991), in these two cases the terms of trade that clears the markets for internationally traded goods will result in balanced trade period by period and will replicate the period by period consumption allocations in the home and foreign countries that would result in a world with a complete 
set of contingent claims markets. In a Cole Obstfeld world, trade in goods is - macro economically - equivalent to trade in assets.

Because in these cases trade is balanced period by period, in equilibrium income will equal expenditure and there will be an exact linear relationship between $c_{t}, y_{t}$, and $s_{t}$ each period given by $\mathrm{c} t_{t}=y_{t}+\gamma S_{t}$. Substituting this consumption index in 2), we obtain an open economy 'IS' equation $y_{t}=E_{t} y_{t+1}+\gamma s_{t}-\gamma E_{t} s_{t+1}-\sigma^{-1}\left(R_{t}-E_{t} \pi t+1-\gamma E_{t} \Delta s_{t+1}\right)$. As in static models, a terms of trade worsening today boosts exports and increases demand for domestic output. Also note that an anticipated terms of trade worsening in the future raises expected CPI inflation and lowers the consumption real interest rate for any given nominal interest rate which will tilt consumption demand toward the present.

With balanced trade and identical preferences goods market equilibrium will imply an exact linear relationship between $\mathrm{st}_{\mathrm{t}} \mathrm{yt}_{\mathrm{t}}$ and $\mathrm{y}^{*}$ given by $s_{t}=y_{t}-y^{*}$ which we can use to substitute out for St in the open economy 'IS' curve. After some simplification we obtain

$$
\tilde{y}_{t}=E_{t}\left\{\tilde{y}_{t+1}\right\}-\sigma_{0}^{-1}\left[R_{t}-E_{t}\left\{\pi_{t}+1\right\}-\overline{r r} t\right]
$$

where a tilde over a variable, $\tilde{y}_{t}$, indicates log deviation from its flexible price equilibrium level which is indicated with an overstrike, $\bar{y}_{t}$. The neutral equilibrium real rate consistent with flexible prices is given by

$$
\overline{r r}_{t}=\sigma_{0} E_{t}\left\{\Delta \bar{y}_{t}+1\right\}+k_{0} E_{t}\left\{\Delta y_{t+1}^{*}\right\}
$$


where $\sigma_{0}=\sigma-\gamma(\sigma-1)>0, \kappa_{0}=\gamma(\sigma-1)$, and $\Delta y^{*}{ }_{t+1}$ is growth in foreign output. In our benchmark case $\sigma \geq 1$ and thus $\kappa_{0} \geq 0$. In other worlds, unless $\sigma=1$ the neutral real interest rate in the home country will in general be proportional to an average of domestic potential and world growth rates. Finally we note that the log of potential output will be given by

$$
\bar{y}_{t}=\kappa^{-1}\left[(1+\phi) a_{t}-\kappa_{0} y_{t}^{*}\right]
$$

where $\kappa=\sigma(1-\gamma)+\gamma+\phi$.

As is the case for the Euler equation, we can substitute out for consumption and the terms of trade and obtain the structural Phillips curve that will prevail in the open economy under conditions discussed above. We see that $m c t=\mu^{w} t+\kappa y_{t}+\kappa o y^{*}-(1+\phi) a_{t}$. However, using the equilibrium condition for potential output $\bar{y}_{t}=\kappa^{-1}\left[(1+\phi) a_{t}-\kappa_{0} y_{t}^{*}\right]$, it must be the case that the equation for real marginal cost simplifies to $m c_{t}=\kappa \tilde{y}_{t}+\mu_{t}^{w}$ from which we obtain

$$
\pi_{t}=\beta E t\left\{\pi_{t+1}\right\}+\{\sigma(1-\gamma)+\gamma+\varphi\} \delta \tilde{y}_{t}+u_{t}
$$

with $\lambda=\{\sigma(1-\gamma)+\gamma+\phi\} \delta$ and $u_{t}=\delta \mu^{w_{t}}$. We note that in the baseline case. the more open is the economy the flatter is the Phillips curve relationship between the output gap and inflation. 


\section{Optimal Monetary Policy in the Open Economy}

To solve for optimal monetary policy in the open economy we need to specify the central bank of objective function. There are two ways to do this. We can just assume - as in the closed economy analysis of Clarida, Gali and Gertler (1999) much of the 'pre-Woodford' international monetary literature - that the objective function is quadratic in inflation and the output gap with an arbitrary relative weight $\alpha$ on stabilizing output at its natural level $\bar{y}_{\mathrm{t}}$. Or, as was derived in Clarida, Gali and Gertler (2002) and Gali Monacelli (2005), we can follow Woodford (2003) and solve for $\alpha$ - and thus the optimal policy rule - as a function of deep parameters. Under either approach, it is important to note that, absent a fiscal policy, even under flexible prices the economy will be distorted away from the first best equilibrium. This is due to the market power that heterogeneous workers have in the labor market and that input producers have in the goods market. A welfare maximizing policy will want to offset these distortions with a wage subsidy that is financed via a lump sum tax. As in Woodford (2003) we assume this is done. However, as was pointed out by Corsetti and Pesenti (2001), in an open economy there will be an incentive for policy to restrict output below its competitive flexible price level to take advantage of the imperfect substitutability between imported and exported consumption goods. In order to avoid the time consistency issues (Kydland-Prescott (1977)) that would arise, we follow Clarida , Gali, Gertler (2002) and assume the employment subsidy is set so that the central bank has no incentive to engineer a surprise depreciation or appreciation of its exchange rate. This subsidy will satisfy $(1-\tau)\left(1+\mu^{w}\right)\left(1+\mu^{p}\right)(1-\gamma)=1$

So for a policymaker that wants to maximize an objective function proportional to

$$
W^{H}=-E_{0} \sum_{t=0}^{\infty} \beta^{t}\left[\pi_{t}^{2}+\alpha \tilde{y}_{t}^{2}\right]
$$

subject to 3 ) and 4) and taking $y^{*}$ and $E_{t} \pi_{t+1}$ as given, the first order condition will be given by 


$$
\tilde{y}_{t}=-\frac{\lambda}{\alpha} \pi_{t}
$$

which is of the same form as in Clarida, Gali and Gertler (1999). Since under optimal policy the output gap will be linear in inflation, the equilibriums rate of inflation under optimal policy will satisfy $\pi_{t}=\beta E_{t}\left\{\pi_{t+1}\right\}-\left(\lambda^{2} / \alpha\right) \pi_{t}+u_{t}$. Solving forward and assuming $u_{t}=\rho u_{t-1}+\varepsilon_{t}$ we obtain $\pi_{t}=\left(1-\beta \rho+\lambda^{2} / \alpha\right)^{-1} \mathcal{u}_{t}$. Thus as is well known, for the case of an entirely forward looking Euler equation and Phillips curve, there will be no endogenous dynamics and inflation, the output gap, and the terms of trade of trade will inherit the exogenous dynamics of the cost push shock. In the next section we show how this model can easily be generalized - via a hybrid Phillips curve - to incorporate endogenous dynamics and work out the implication for the nominal exchange rate.

The optimal policy rule given $\alpha$ is obtained by substituting the first order condition into 3) and using equilibriums dynamics for inflation. In terms of endogenous variables we see that

$$
R_{t}=\overline{r r}_{t}+\left(1+\frac{\lambda(1-\rho)}{\alpha \rho} \sigma_{0}\right) E_{t} \pi_{t+1}
$$

with again $\sigma_{0}=\sigma-\gamma(\sigma-1)$ and $\lambda=\{\sigma(1-\gamma)+\gamma+\phi\} \delta$. Thus optimal policy in the open economy can be written as a forward looking Taylor rule with a time varying neutral real interest rate given by $\overline{r r}_{t}=\sigma_{0} E_{t}\left\{\Delta \bar{y}_{t+1}\right\}+k_{0} E_{t}\left\{\Delta y_{t+1}^{*}\right\}$. Unless $\sigma=1$, there will in general be spillovers from foreign output growth to the home flexible price equilibrium and under optimal monetary policy this will be reflected in the neutral real interest rate. Of course the policy rule can also always be written as a linear function of the exogenous state vector $\left[a_{t}, a^{*} t, u_{t}, u^{*}\right]^{\prime}$. 
What are the implications of optimal policy for the nominal exchange rate? We note that $e_{t}=e_{t-1}+\Delta s_{t}+\pi t-\pi^{*}$ and that $s_{t}=\tilde{y}_{t}-\tilde{y}_{t}^{*}+\bar{y}_{t}-\bar{y}_{t}^{*}$. Using the fact that

$$
\begin{aligned}
& \bar{y}_{t}=\kappa^{-1}\left[(1+\phi) a_{t}-\kappa_{0}\left(\tilde{y}_{t}^{*}+\bar{y}^{*}{ }_{t}\right)\right] \\
& \bar{y}_{t}^{*}=\kappa^{*-1}\left[(1+\phi) a^{*}{ }_{t}-\kappa^{*}{ }_{0}\left(\tilde{y}_{t}+\bar{y}_{t}\right)\right]
\end{aligned}
$$

we can solve for flexible price output levels under optimal policy in terms of exogenous productivity and cost push shock terms. For the symmetric case $\gamma=1 / 2$ this simplifies to

6)

$$
e_{t}=e_{t-1}-\left(w \frac{\lambda}{\alpha}-1\right) \psi\left(u_{t}-u_{t}^{*}\right)+\frac{w \lambda}{\alpha} \psi\left(u_{t-1}-u_{t-1}^{*}\right)+\left(\Delta a_{t}-\Delta a_{t}^{*}\right)
$$

where $\mathrm{w}=\frac{1}{2}\left(1+\frac{\sigma+\phi}{1+\phi}\right)$ and $\psi=\left(1-\beta \rho+\lambda^{2} / \alpha\right)^{-1}$.There are five important implications of 6$)$.

First, optimal monetary in this class of models with nominal rigidities will feature a flexible exchange rate. The exchange rate regime is not assumed or imposed on the analysis - it arises endogenously from the environment with a policymaker who maximizes the welfare of domestic households. Second, not only does optimal monetary policy feature a flexible exchange rate, the equilibrium exchange rate must possess a unit root even though shocks are stationary and our Cole-Obstfeld equilibrium replicates the complete market allocation. Third, so long a relative home and foreign productivity levels $a_{t}-a^{*}$ are stationary, then so too will be the equilibrium terms of trade $\mathrm{St}_{\mathrm{t}}$ and this will imply that the nominal exchange rate is co integrated with relative home and foreign price levels $p_{t}-p^{*}$. Thus the nominal exchange rate must possess a unit root because time consistent monetary policy cannot deliver a stationary price level, only a stationary rate of inflation around a zero mean (C Clarida, Gali and Gertler (1999); Woodford (2003)). The unit root in the nominal exchange rate is required to produce a stationary equilibrium terms of trade given that optimal monetary policy produces unit root price levels at home and abroad that themselves 
are not co integrated. Fourth, in the symmetric two country model presented here bad news about inflation will be good news for the nominal exchange rate under optimal monetary policy so long as $\alpha$, the relative weight placed on stabilizing output, is not too large. A 'cost push' shock ut will increase domestic inflation and under optimal policy induce the central bank to raise the nominal interest rate by more than expected inflation. The rise in the ex-ante real interest rate will cause st to fall and this, along with the rise in the real interest rate itself, will reduce demand for home output. In the 'bad news good news' case the equilibrium decline in St is larger in absolute value than is the equilibrium rise in inflation, and thus can only be accomplished via an appreciation of the nominal exchange rate. This is so even though, because of the unit root in the home price level, the nominal exchange rate is expected to depreciate in the long run in response to a cost push shock today. As is evident from inspection of 6), a necessary and sufficient condition for the 'bad news good news' result is simply that $\alpha<w \lambda$. In the baseline case with $\sigma \geq 1$ this will always be satisfied so long as $\alpha<\lambda$; that is - if the relative weight on the output term in the welfare function is less than the slope of the Phillips curve, then bad news for inflation must be good news for the nominal exchange rate.

Thus far, we have taken $\alpha$ to be a primitive. However, as confirmed in Clarida, Gali and Gertler (2002) and Gali Monacelli (2005), Woodford's (2003) derivation of the quadratic approximation to the welfare function of the representative agent actually pins down $\alpha$ as a function of deep parameters. And indeed as in Woodford's (2003) closed economy analysis Clarida, Gali and Gertler (2002) show that $\quad \alpha=\lambda / \xi$ with $\xi>1$ in the open economy as in the closed. Thus for the baseline $\sigma \geq 1$ case, with $\alpha$ chosen optimally, bad news for inflation must be good news for the nominal exchange rate in the symmetric equilibrium. 


\section{Robustness}

In the two country model analyzed here, there will gains to international policy cooperation unless $\sigma=1$. It is natural to ask if the key conclusions discussed above are robust in an equilibrium where monetary policy is chosen to maximize world welfare and incorporates the gains from international policy cooperation that are ignored in the Nash equilibrium. At least in the model of Clarida, Gali and Gertler (2002) and the important extension in Engel (2009) - who allows for currency mis-alignment, home bias in preferences, and local currency pricing (all of which are absent in Clarida, Gali and Gertler (2002)) - the answer is yes. Under cooperation, a regime of flexible exchange continues to be optimal and the exchange rate will continue to possess a unit root because again, in the absence of the commitment device, home and foreign price levels are non-stationary and importantly are themselves not co integrated with each other. The mirage of fixed exchange rates continues to be a mirage. And at least for the symmetric equilibrium in the two country model, bad news about inflation will continue to be good news for the nominal exchange rate under optimal cooperative monetary policy.

Moreover, under cooperative policy a version of a Taylor rule continues to characterize the optimal monetary policy in the open economy, with the simple difference that the monetary policy rule in each country under cooperation reacts to an average of foreign as well as home inflation - producer price inflation in the case of Clarida, Gali and Gertler and CPI inflation in Engel (2009) - the with the relative weights on the two a function of the importance of international spillovers. In particular, under cooperation the policy rule is given by

$$
R_{t}=\overline{r r}_{t}+\left(1+\frac{\lambda(1-\rho)}{\alpha \rho} \sigma_{0}\right) E_{t} \pi_{t+1}+\frac{\kappa_{0} \lambda(1-\rho)}{\kappa \alpha \rho} \sigma_{0} E_{t} \pi_{t+1}^{*}
$$




\section{A Model with Endogenous Dynamics}

Clarida-Waldman (2014) work with a version of the Gali-Monacelli (2005) DSGE model that can produce endogenous dynamics in output, inflation, and deviations from PPP. The model features a hybrid Phillips curve (Gali-Gertler (1999)) and allows for home bias in consumption, and thus transitory deviations of the CPI real exchange rate from long run PPP. We preserve the Cole Obstfeld structure by assuming Cobb-Douglas utility but with home bias and $\sigma=1$, so there will be no cross country spillovers impacting potential output. We treat $\log$ foreign output, the foreign interest rate, and foreign inflation as exogenous, constant (as in Gali and Monacelli (2005) and De Paoli (2009)), and equal to zero.

Goods market equilibrium requires $\gamma N Y_{t} / S_{t}+\left(1-\gamma^{*}\right) N^{*} Y^{*}{ }_{t}=N^{*} Y^{*}$ where $\mathrm{N}$ is population of home country and $\mathrm{Y}^{*}$ is per capita foreign output. This implies

$$
S_{t}=\frac{\gamma}{\gamma^{*}} \frac{N}{N^{*}} \frac{Y_{t}}{Y_{t}^{*}}
$$

We assume the share of foreign spending on the home good satisfies $\gamma^{*}=\gamma\left(\mathrm{N} / \mathrm{N}^{*}\right)$ so that $S_{t}=Y_{t} / Y^{*}$ exactly for any $\left(N / N^{*}\right)$ so $s_{t}=y_{t}-y_{t}^{*}$. Note also that an appeal of this formulation is that the goods market equilibrium condition is invariant to $\left(\mathrm{N} / \mathrm{N}^{*}\right)$ while the share of foreign spending on home output converges to zero as does $\mathrm{N} / \mathrm{N}^{*}$. The 'IS' curve simplifies to

$$
\tilde{y}_{t}=E_{t}\left\{\tilde{y}_{t+1}\right\}-\left[R_{t}-E_{t}\left\{\pi_{t}+1\right\}-\bar{r} r_{t}\right]
$$

with $\overline{r r}_{t}=E_{t}\left\{\Delta a_{t+1}\right\}$ and $\bar{y}_{t}=a_{t}$. 
We assume a Gertler-Gali (1999) hybrid Phillips curve emerges because a constant fraction of price re setters each period use a rule of thumb based on lagged inflation to set prices

$$
\pi_{t}=\chi_{f} E_{t} \pi_{t+1}+\chi_{b} \pi_{t-1}+\delta_{\chi} m c_{t}
$$

where the parameters $\chi_{f}, \chi_{b}$, and $\delta_{\chi}$ are functions of the fraction of rule of thumb price setters as well as the Calvo parameters F and $\beta$. Under our assumption on preferences and using the goods market equilibrium condition, we can substitute for real marginal cost to obtain

$$
\pi_{t}=\chi_{f} E_{t}\left\{\pi_{t+1}\right\}+\chi_{b} \pi_{t-1}+\{1+\varphi\} \delta_{\chi} \tilde{y}_{t}+u t
$$

where we now have $\lambda=(1+\phi) \delta$. To focus on endogenous persistence, we now assume $u$ tis white noise. With home bias, the CPI real exchange is given by $Q_{t}=E_{t} P^{* c p i_{t}} / P c i_{t}=\left(k / k^{*}\right) S_{t}{ }^{1-\gamma^{*}-\gamma}$ where $k=(1-\gamma)^{(1-\gamma)} \gamma^{\gamma}$ and similarly for $k^{*}$. Recall $\gamma$ is share of home spending on foreign good while 1- $\gamma^{*}$ is share of foreign spending on foreign good. With home bias, the CPI real exchange rate will reflect fluctuations in equilibrium terms of trade.

The isomorphism result is very useful because the policymaker that wishes to maximize

$$
W^{H}=-E_{0} \sum_{t=0}^{\infty} \beta^{t}\left[\pi_{t}^{2}+\alpha \tilde{y}_{t}^{2}\right]
$$

subject to $3^{\prime}$ ) and $4^{\prime}$ ) as well as an assumed law of motion for inflation

$$
\pi_{t}=a_{\pi} \pi_{t}+a_{u} u_{t}
$$


faces exactly the same problem as the policymaker in Clarida, Gali and Gertler (1999) Section 6. What the policy maker takes as given, accordingly, is not the level of expected inflation, but rather how private sector expectations of inflation tomorrow respond to movements in inflation today. To solve for the equilibrium we assume that private sector forecast of $\pi_{t+1}$ takes the form $v_{\pi} \pi_{t}+v_{u} u_{t}$, where $v_{\pi}$ and $v_{u}$ are arbitrary constants that the policy-maker takes as given. In the rational expectations equilibrium $v_{\pi}$ and $v_{u}$ equal the true fundamental parameters in the reduced form inflation equation, $a_{\pi}$ and $a_{u}$. And of course $a_{\pi}$ and $a_{u}$ must be consistent with the inflation dynamics implied by $\left.3^{\prime}\right) 4^{\prime}$ ) and the policy rule.

The first order condition for this problem is

$$
\tilde{y}_{t}=-\frac{\lambda}{\alpha\left(1-\beta a_{\pi}\right)} \pi_{t}
$$

where we note that optimal policy with endogenous inflation inertia calls for a more aggressive response to inflation deviations from target than for the case of exogenous costs push persistence. Using the goods market equilibrium condition and recalling that $q_{t}=\left(1-\gamma^{*}-\gamma\right)_{S t}$ we see that under optimal policy

$$
q_{t}=\left\{1-\gamma^{*}-\gamma\right\}\left(-\frac{\lambda}{\alpha\left(1-\beta a_{\pi}\right)}\right) \pi_{t}+\left\{1-\gamma^{*}-\gamma\right\} a_{t}
$$

where $\mathrm{q}_{\mathrm{t}}$ is the log deviation of the CPI real exchange rate from the steady state value of 0 .

We seek a fixed point for $\mathrm{a}_{\pi}$ by substituting the first order condition into $4^{\prime}$ ) and imposing the law of motion 7) on expected inflation

$$
\pi_{t}=\chi_{f} a_{\pi} \pi_{t}+\chi_{b} \pi_{t-1}-\frac{\lambda^{2}}{\alpha\left(1-\beta a_{\pi}\right)} \pi_{t}+u_{t}
$$


Collecting terms we see that

$$
\pi_{t, t}\left(1-\chi_{f} a_{\pi}+\frac{\lambda^{2}}{\alpha\left(1-\beta a_{\pi}\right)}\right)=\chi_{b} \pi_{t-1}+u_{t}
$$

We see immediately that the fixed point $a_{\pi}$ must satisfy

8)

$$
\left(1+\frac{\lambda^{2}}{\alpha\left(1-\beta a_{\pi}\right)}\right)=\chi_{b} / a_{\pi}+\chi_{f} a_{\pi}
$$

Existence of a fixed point for $\mathrm{a}_{\pi}$ in the compact set $[0,1]$ is insured for all admissible parameters so long as $\chi_{f}+\chi_{b} \leq 1$ which is always the case in the Gali- Gertler (1999) formulations of the 'hybrid Phillips curve. Moreover, for a standard parameterization ( $\xi=10, \phi=1, \beta=0.99, F=0.75)$ the Blanchard - Kahn conditions (1979) for uniqueness (in this case, that one root of the cubic be stable and the other two have modulus greater than unity) are satisfied for all feasible choices for the share of backward looking price setters.

Figure 1 depicts the determination of $a_{\pi}$ as a function of $\alpha$ and is the DSGE model analogue to Figure 1 in Clarida Waldman (2008) paper which studied a similar but ad hoc model with $\chi_{f}=0$. We see immediately that

Result One: Equilibrium inflation inertia as well as the half-life of deviations from PPP in response to cost push shocks are monotonically increasing in $\alpha$, the relative weight on output stabilization in the central bank welfare function.

Under optimal policy the nominal exchange rate must satisfy

9)

$$
e_{t}=\left(-\frac{\lambda}{\alpha\left(1-\beta a_{\pi}\right)}+1\right) \pi_{t}+a_{t}+p_{t-1}
$$


where we have used the first order condition plus the equilibrium condition for terms of trade and the definition of the nominal exchange rate. The following results follows immediately.

Result Two: Bad News for inflation must be Good News for the nominal exchange rate if $\alpha<\lambda$.

Result Three: Bad news for inflation must be Good News for the nominal exchange rate if $\alpha$ is equal to its optimal value $\alpha=\lambda / \xi$.

We gain insight into these results by deriving the optimal policy rule as before. It takes the form

$$
R_{t}=E_{t} \Delta a_{t+1}+\left(1+\frac{\lambda\left(1-a_{\pi}\right)}{\alpha\left(1-\beta a_{\pi}\right) a_{\pi}}\right) E_{t} \pi_{t+1}
$$

We note that in this $\sigma=1$ case, while economies can differ in their degree of openness, if their policymakers share the same $\alpha$ and their economies same structure, they will run the same optimal policy rule. This policy rule in turn will imply that a shock to inflation in time $t$ will impact the entire expected future time path of the ex-ante real policy rate as of time $t$. It is straightforward to show that in equilibrium with $\lim i \rightarrow \infty \quad E_{t} S_{t+i}=0$ we must have

$$
e_{t}=p_{t}-p_{t}^{*}-E_{t} \sum_{i=0}^{\infty}\left(R_{t+i}-\pi_{t+i+1}\right)=p_{t}-p_{t}^{*}-E_{t} \sum_{i=0}^{\infty} \Delta a_{t+i+1}-\frac{\lambda\left(1-a_{\pi}\right)}{\alpha\left(1-\beta a_{\pi}\right)} E_{t} \sum_{i=0}^{\infty} \pi_{t+i+1}
$$

Thus the exchange rate is an asset price that is the sum of three terms: a purchasing power parity term (the source of the unit root), a term reflecting the path of expected future productivity growth, and a term reflecting the expected time path of future inflation. So via the Taylor rule the macro drivers of the optimal policy rate become the macro factors of the nominal exchange rate pinned down by the parameters of the optimal Taylor rule as well as the endogenous rate of inflation inertia. 


\section{Concluding Remarks}

The models outlined above are simple - but solvable! - and do omit a number of important considerations such as endogenous capital accumulation, current account imbalances, and imperfect financial markets, the latter of which can open the door to nominal exchange rate volatility unrelated macro fundamentals. And in practice, several inflation targeting central banks do appear to allow the policy rate to react directly to exchange rate deviations from PPP over and above any information that said PPP deviations provide for forecasting inflation itself (Clarida , Gali , Gertler (1998); Lubik and Schorfheide (2003) Engel and West (2006); Engel, Mark, and West (2007)). That said, at least to this author, the framework outlined above does provide a useful construct for thinking about monetary policy in the open economy and understanding what it can deliver and what it can't. The framework suggests that good macroeconomic outcomes in open economies are possible by focusing inflation targeting that is implemented by a Taylor type rule, a rule that in equilibrium is reflected in the exchange rate as an asset price just as it is reflected in long term bond yields via the expectation channel for the expected future policy rate (Ang and Piazzesi (2003)). Optimal monetary policy will not be able deliver a stationary ('stable') nominal exchange rate - let alone a fixed exchange rate or one that remains inside a target zone - because, absent a commitment device, optimal monetary can't deliver a stationary domestic price level. Moreover, even under cooperation, home and foreign domestic price levels will not be co integrated so a unit root in the nominal exchange rate is necessary to deliver a stationary terms of trade.

Another feature in the data for inflation targeting countries that is consistent with optimal monetary policy via Taylor type rule is that it will tend push the nominal exchange rate in the opposite direction from PPP in response to a 'cost push' shock - the 'bad news god news' result of Clarida -Waldman (2008;2014). This is so even though in the long run of these models 
the nominal exchange rate must in expectation obey PPP. So what at first glance might appear to be an indictment of monetary policy by Taylor rule in the open economy - that it pushes the exchange rate away from PPP in response to inflation shocks - is actually a property of optimal policy!

The model outlined in Section IV also has implications for the Rogoff (1996) PPP puzzle: why are estimated half-lives of PPP deviations on the order of twelve to twenty quarters while estimated half-lives of inflation deviations from target are two to four quarters? Recall that in the model of Section IV the log deviation from PPP is given by

$$
q_{t}=\left\{1-\gamma^{*}-\gamma\right\}\left(-\frac{\lambda}{\alpha\left(1-\beta a_{\pi}\right)}\right) \pi_{t}+\left\{1-\gamma^{*}-\gamma\right\} a_{t}
$$

Now for the special case of no productivity shocks, PPP deviations and inflation deviations from target will have identical half-lives governed by the endogenous rate of inflation persistence $a_{\pi}$. But, if there are stationary (relative) productivity shocks and home bias, the PPP deviation is no longer an $\mathrm{AR}(1)$ but the sum of two $\mathrm{AR}(1)$ processes. And as is well known, the sum of two different $\operatorname{AR}(1)$ processes is an $\operatorname{ARMA}(2,1)$ process. Depending on the persistence of relative productivity shocks and their variance, PPP deviations can have a much longer estimated halflife recovered from a mis-specified $\mathrm{AR}(1)$ model for the real exchange rate than do inflation deviations from target in the model of optimal monetary policy in Section IV.

As of this writing many of the world's major central banks are operating at or close to the zero lower bound for the policy rate. For many of them, Taylor type rules that well accounted for the policy rate before the global financial crisis have implied negative policy rates since 2008 .

That said as economies recover and output gaps close (after adjusting for the impact of the crisis on potential output), central banks will begin to normalize the policy rate. As they do a Taylor rule - with suitable inputs for the expected path of the neutral real interest rate, inflation, and the 
output gap - can be a relevant benchmark for assessing the expected normalization path for the policy rate communicated by the central bank and priced into financial markets (Clarida - Parikh (2014)).

*Paper prepared for the Hoover Institution Conference on Monetary Policy for the 21st Century. I would like to thank the conference organizers, participants, and especially my discussant Maurice Obstfeld as well as Ken Judd for insightful suggestions for future work. 


\section{References}

Ang, A., and M. Piazzesi. "A no-arbitrage vector autoregression of term structure dynamics with macroeconomic and latent variables." Journal of Monetary economics 50.4 (2003): 745-787.

Blanchard, O J, and C. M. Kahn. "The solution of linear difference models under rational expectations." Econometrica (1980): 1305-1311.

Calvo, G., "Staggered Prices in a Utility-Maximizing Framework," Journal of Monetary Economics 12: 383-398 (1983).

Clarida, R. H. "G3 exchange rate relationships: A recap of the record and a review of proposals for change" No. w7434. National bureau of economic research, 1999.

Clarida, R H. "The empirics of monetary policy rules in open economies." International Journal of Finance E Economics 6.4 (2001): 315-323.

Clarida, R., J Gali, and Gertler, “ Monetary Policy Rules in Practice: Some International Evidence," European Economic Review, (1998).

“The Science of Monetary Policy," Journal of Economic Perspectives, (1999).

, “Optimal Monetary Policy in Closed versus Open Economies: an Integrated Approach," No. w8604. National Bureau of Economic Research, 2001

"A Simple Framework for International Monetary Policy Analysis," Journal of Monetary Economics 49: 879-904 (2002).

Clarida, R H., and M Gertler. "How the Bundesbank conducts monetary policy." Reducing Inflation: Motivation and Strategy. University of Chicago Press, 1997. 363-412.

Clarida, R. and S. Parikh: “Guidance Counselors” The International Economy, Spring 2014

Clarida, R and D Waldman, "Is Bad News about Inflation Good News for the Exchange Rate" in John Campbell, Editor, Asset Prices and Monetary Policy, Chicago: University of Chicago Press, 2008.

"Bad News About Inflation is Good News for the Nominal Exchange Rate

Under Optimal Monetary Policy: DSGE Theory and a Decade of Empirical Evidence", in process , 2014

Cole, H L., and M Obstfeld, "Commodity Trade and International Risk Sharing: How Much Do Financial Markets Matter?" Journal of Monetary Economics 28: 3-24 (1991).

Corsetti, G. and P. Pesenti, “Welfare and Macroeconomic Independence," Quarterly Journal of Economics, 2001. 
"International dimensions of optimal monetary policy." Journal of Monetary

economics 52.2 (2005): 281-305.

De Paoli, B. "Monetary policy and welfare in a small open economy."Journal of International Economics 77.1 (2009): 11-22.

Devereux, M B., and V Hnatkovska. Consumption Risk-Sharing and the Real Exchange Rate: Why does the Nominal Exchange Rate Make Such a Difference?. No. w17288. National Bureau of Economic Research, 2011.

Engel, C, and K West," Taylor rules and the deutschmark dollar real exchange rate." Journal of Money, Credit and Banking38.5: 1175-1194, 2006

Engel, C., N. Mark, and K. West," Exchange Models are Not As Bad As You Think?“ , NBER Macro Annual 2007.

Engel, C. Currency misalignments and optimal monetary policy: a reexamination. No. w14829. National Bureau of Economic Research, 2009.

Galí, J. Monetary Policy, inflation, and the Business Cycle: An introduction to the new Keynesian Framework. Princeton University Press, 2009.

Galı, J, and M Gertler. "Inflation dynamics: A structural econometric analysis." Journal of monetary Economics 44.2 (1999): 195-222.

Gali, J, and T Monacelli, "Monetary Policy and Exchange Rate Volatility in a Small Open

Economy," Review of Economic Studies 72: 707-734 (2005)

Krugman, P. M. Obstfeld, M. Melitz, International Economics Prentice Hall Page 2011

Kydland, F E., and E C. Prescott. "Rules rather than discretion: The inconsistency of optimal plans." The Journal of Political Economy (1977): 473-491.

Laubach, T, and J. C. Williams. "Measuring the natural rate of interest." Review of Economics and Statistics 85.4 (2003): 1063-1070.

Lubik, T A., and F Schorfheide. "Do central banks respond to exchange rates? A structural investigation." Journal of Monetary Economics. 2003.

Molodtsova, T, and D H. Papell. "Out-of-sample exchange rate predictability with Taylor rule fundamentals." Journal of International Economics77.2 (2009): 167-180.

Obstfeld, M. and K. Rogoff, Foundations of International Macroeconomics, MIT Press, 1997.

"New directions for stochastic open economy models." Journal of international economics 50.1 (2000): 117-153. 
Obstfeld, M. "Inflation-targeting, exchange-rate pass-through, and volatility." American Economic Review (2002): 102-107.

Svensson, L. E.O., “Open-Economy Inflation Targeting," Journal of International Economics 50: 155183 (2000).

Taylor, J, B., 1982, Macroeconomic tradeoffs in an international economy with rational expectations, in: Hildebrand, ed., Advances in economic theory (Cambridge University Press, Cambridge).

Macroeconomic Policy in a World Economy: From Econometric Design to Practical Operation, W.W. Norton, New York, 1993.

"Discretion Versus Policy Rules in Practice," Carnegie-Rochester Series on Public

Policy, North-Holland, 39, 1993, pp. 195-214.

White, W., "Globalization and the Determinants of Domestic Inflation," BIS Working Paper No. 250, March 2008.

Woodford, M , Interest and Prices: Foundations of a Theory of Monetary Policy, Princeton: Princeton University Press, 2003.

Globalization and Monetary Control, in Galí, Jordi, and Mark Gertler, eds. International Dimensions of Monetary Policy. University of Chicago Press, 2010. 
TABLE 1

The Original Clarida - Waldman (2008) Result for the July 2001 - December 2005 Sample

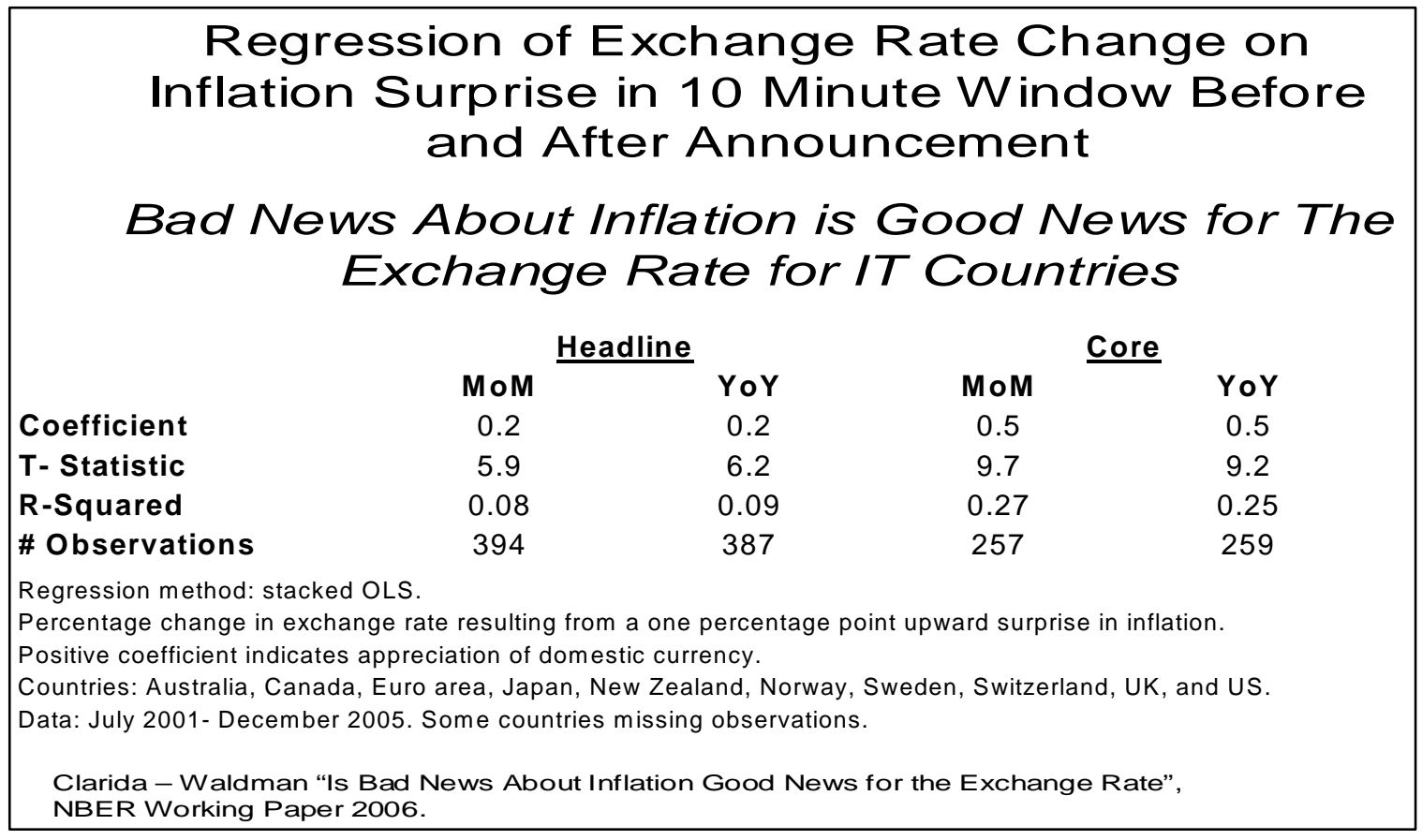


TABLE 2

Updated Clarida - Waldman (2014) Result for July 2001- December 2013 Sample

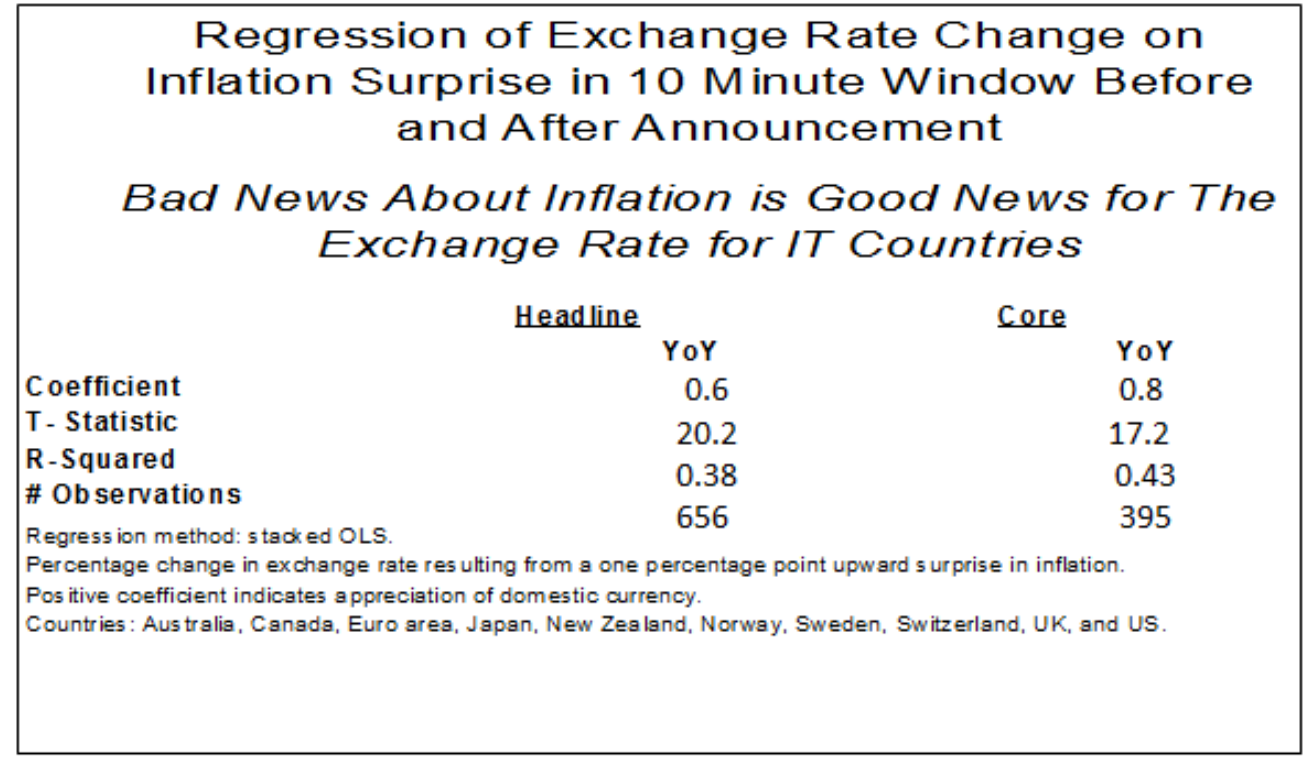




\section{FIGURE 1}

Fixed Point Solution for $\mathrm{a} \pi$ as function of $\lambda / \alpha$

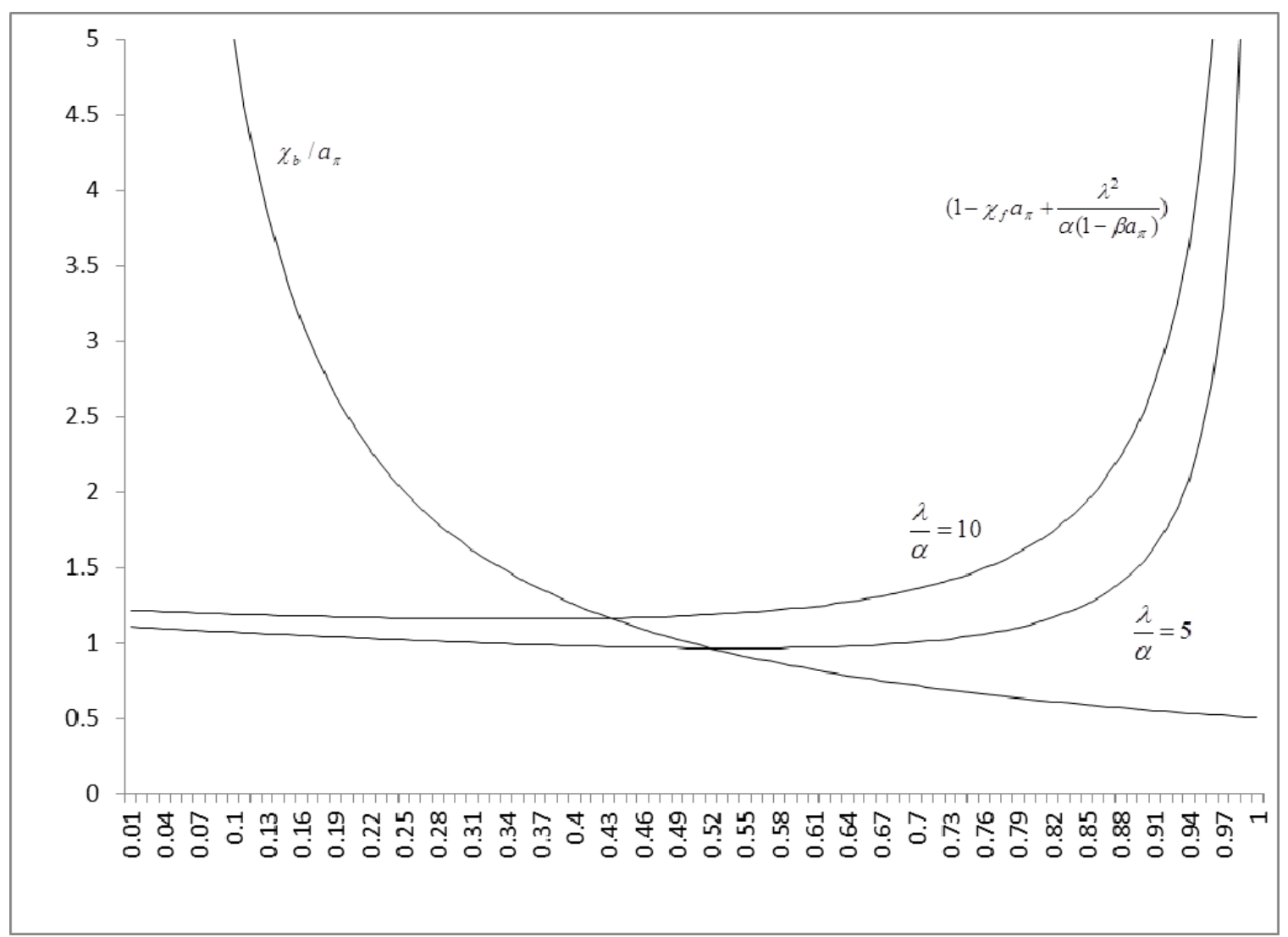

